\title{
Spontaneous rectus sheath haematoma secondary to severe coughing in a patient with no other precipitating factors
}

\author{
Shil Patel, Braghadheeswar Thyagarajan, Ishan Lalani
}

Department of Internal

Medicine, Monmouth Medical Center, Long Branch,

New Jersey, USA

\section{Correspondence to} Dr Braghadheeswar Thyagarajan,

bragmd@gmail.com

Accepted 16 January 2016

\section{DESCRIPTION}

A 62-year-old woman with a past medical history significant only for hypertension and hypothyroidism presented to the emergency department (ER), with right lower quadrant pain. She had, 1 day prior to the day of admission, been treated for bronchitis as an outpatient. She continued to experience multiple episodes of cough at home and eventually developed abdominal pain, which brought her to the ER. Her vitals were within normal limits and physical examination was significant for tenderness on palpation in the right lower quadrant of her abdomen, with guarding. Her blood work was significant for haemoglobin of $6.5 \mathrm{~g} / \mathrm{dL}$. Our initial impression was acute appendicitis and internal haemorrhage.

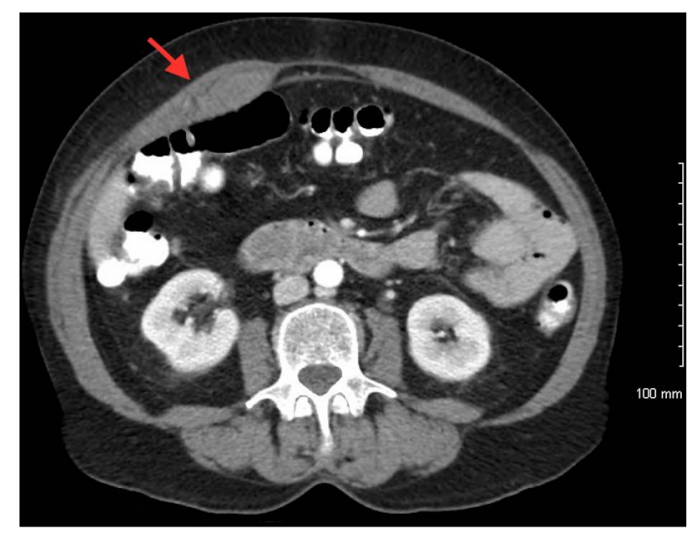

Figure 1 Axial view of CT of the abdomen with contrast showing haematoma between the rectus abdominis sheath at the level of the kidneys.

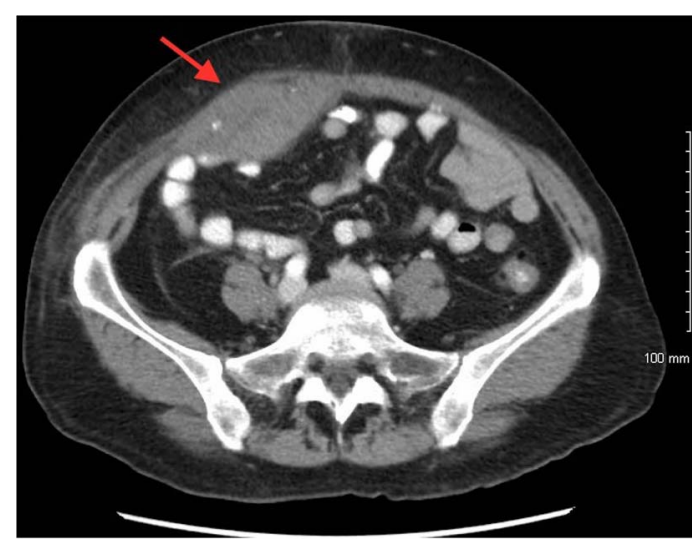

Figure 2 Axial view of CT of the abdomen with contrast showing haematoma between the rectus abdominis sheath below the level of kidneys.

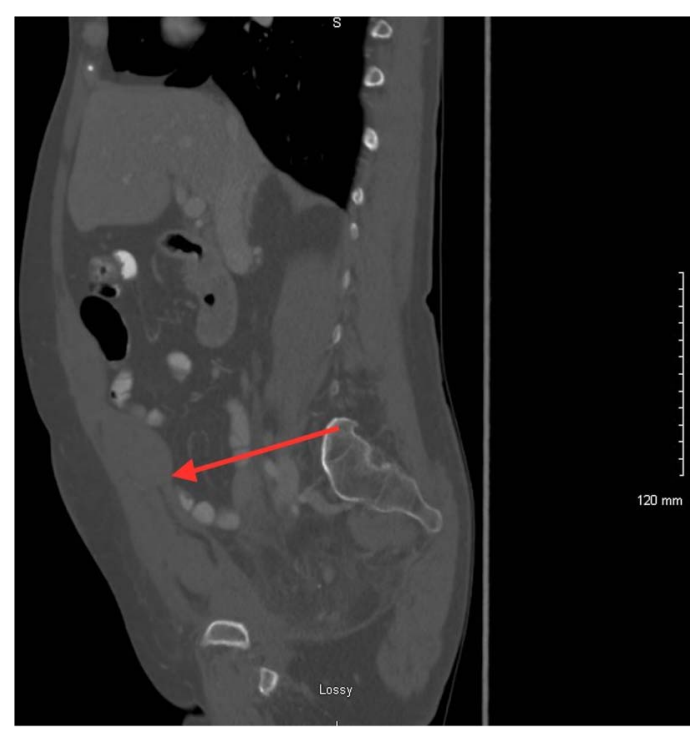

Figure 3 Sagittal view of CT of the abdomen with contrast showing haematoma between the rectus abdominis sheath.

CT scan of the abdomen and pelvis with contrast revealed a large right sided haematoma within the rectus abdominis sheath (figures 1-3). The patient was not on any anticoagulation or antiplatelet agent. She was transfused with 2 units of packed red blood cells, her pain was managed with medications and ice packs and cough was controlled with antitussives. Clinically, the patient improved and subsequent blood work revealed stable haemoglobin.

\section{Learning points}

- In patients presenting with acute abdominal pain without obvious precipitating factors, an abdominal wall haematoma should be taken into consideration.

- Ultrasonography is a useful and inexpensive initial test while CT scan remains the preferred diagnostic test for abdominal wall haematoma.

- Conservative management should be considered in contained haematomas without signs of growth or additional bleeding.

- Usually, cough is considered benign and often undertreated, it can lead to rupture of fragile blood vessels, which can lead to conditions such as haematoma and haemoptysis. 
Common causes of rectus sheath haematoma are trauma, pregnancy, collagen disorders, muscle disorders, anticoagulation and exercise. Straining during defaecation or coughing can also cause spontaneous rectus sheath haematoma, but often these patients are taking some form of anticoagulation or antiplatelet therapy. ${ }^{1}$ Even though ultrasonography can be a useful initial test, CT scan is the diagnostic imaging of choice. ${ }^{2}$ Management is usually conservative, focusing on correcting the anaemia and reversal of the anticoagulation if indicated. Surgery is indicated in cases of infection, severe pain or rupture into peritoneal cavity. ${ }^{3}$

Acknowledgements Department of Internal Medicine, Monmouth Medical Center, NJ, USA.

Contributors SP contributed to the clinical care of the patient and also to the design, implementation and intellectual content of the article. BT contributed to the design and intellectual content of the article. IL contributed to the intellectual content and to reviewing the article. All the authors have reviewed and approved the final manuscript.

Competing interests None declared.

\section{Patient consent Obtained.}

Provenance and peer review Not commissioned; externally peer reviewed.

\section{REFERENCES}

1 Cherry WB, Mueller PS. Rectus sheath hematoma: review of 126 cases at a single institution. Medicine (Baltimore) 2006;85:105-10.

2 Moreno Gallego A, Aguayo JL, Flores B, et al. Ultrasonography and computed tomography reduce unnecessary surgery in abdominal rectus sheath haematoma. Br J Surg 1997:84:1295-7.

3 Dubinsky IL. Hematoma of the rectus abdominis muscle: case report and review of the literature. J Emerg Med 1997;15:165-7.

Copyright 2016 BMJ Publishing Group. All rights reserved. For permission to reuse any of this content visit http://group.bmj.com/group/rights-licensing/permissions.

BMJ Case Report Fellows may re-use this article for personal use and teaching without any further permission.

Become a Fellow of BMJ Case Reports today and you can:

- Submit as many cases as you like

- Enjoy fast sympathetic peer review and rapid publication of accepted articles

- Access all the published articles

- Re-use any of the published material for personal use and teaching without further permission

For information on Institutional Fellowships contact consortiasales@bmjgroup.com

Visit casereports.bmj.com for more articles like this and to become a Fellow 